\title{
Competitiveness Effect of Sharing Economy. World and Ukrainian Realities
}

\author{
Victortya V. Gonchari, Tetiana V. Gorokhova ii, OLeKsandr V. Kalininiii
}

\begin{abstract}
In modern life, the consumption is an inseparable part of life. However, in recent years there were a lot of discussion about the negative consequences of the growth of consumption, due to limited resources, overpopulation of Earth, uneven distribution of natural wealth and climate change. Awareness of these issues has received a response in a number of developed countries in the form of occurrence of an alternative economy. The principles of the economy are built on the negation of the values of consumerism and non-permanent race for commodities. This type of economy, called sharing economy is the social and economic model, where people have access to the collective consumption. It is worth to be mentioned that there is no enough scientific works devoted to the issue and it is still not researched well. This explains the urgency of the chosen theme. The main aspects of birth of sharing economy, advantages major risks associated with the development of sharing economy were analyzed in the article. We considered and analyzed the main sharing economy international practices and generalized Ukrainian experience in the implementation of sharing economy projects. The number of companies from the spheres of the sharing economy is constantly growing. Capitalization of these companies (both private and public) is also growing at a rapid rate. These companies also fall into the list of the most promising start-ups and introduce innovations into their business process. The companies of this sphere are increasingly competing with the leaders of the markets on which they are represented. It can also be said that these enterprises are re-forming markets and relations on them. Based on these facts, we can say that the interest of science in this topic is relevant. In the article the main spheres of the sharing economy for today and the largest companies from these segments were investigated. Also, a study was carried out of the countries in which these companies are most actively developing with growth forecasting, and conclusions were drawn regarding the development of these segments, especially on developing wounds.
\end{abstract}

Keywords: sharing economy, collaborative consumption, startup.

Abbreviations:

IT - information technology;

PSS - Product-service systems.

УДК 330.3

JEL Codes: M13, M31, F23

Introduction. In recent years, traditional business felt new and unexpected type of competition: self-organization of individuals with the help of online platforms. Services of Search for travel companions take away customers from transport companies, web-sites of a short-term housing rental - from hoteliers and users of freelance resources - from design bureau.

${ }^{i}$ Victoriya V. Gonchar, Dr. (Economics), Associate Professor, Head of the Department of Marketing and Business-Administration, State Higher Educational Institution Pryazovskyi State Technical University (PSTU);

${ }^{i i}$ Tetiana V. Gorokhova, C.Sc. (Economics), Associate Professor of the Department of Marketing and BusinessAdministration, State Higher Educational Institution Pryazovskyi State Technical University (PSTU);

iii Oleksandr V. Kalinin, C.Sc. (Economics), Associate Professor of the Department of Marketing and BusinessAdministration, State Higher Educational Institution Pryazovskyi State Technical University (PSTU).

(C) V. V. Gonchar, T. V. Gorokhova, O. V. Kalinin, 2018.

https://doi.org/10.21272/mer.2018.80.05 
Problem statement. We can see that the great number of companies of sharing economy is very popular among investors. These companies have taken over a great part of traditional markets such as car rentals, real estate, electronics etc. That is why this topic is very applying to scientific sphere to define that major competitive advantages of sharing economy / The Modern scientific and practical approaches to analyzing sharing economy in different countries, regions and worldwide have been studied in the works of R. Botsman [1], H. Heinrichs [8], A. Fellander [6], L. Vitaud [3].

The name for this phenomenon has already been found: the sharing economy. Sharing economy is an economy of resources free exchange and collective consumption.

The purpose of the research is to analyze the main sharing economy international practices and generalized Ukrainian experience in the implementation of sharing economy projects.

Results of the research. During the global financial and economic crisis of 2008 some alternative perspectives on capitalism and consumerism have been voiced. Between the poles of "repairing" and making less regulated existing "system" and radical alternatives to a capitalist market society, a third perspective has gained attention. The concept and practice of a "sharing economy" and "collaborative consumption" suggest making use of market intelligence to foster a more collaborative and sustainable society. Prominent examples are bike- and carsharing schemes as well as web-based peer-to-peer platforms covering a broad range of activities from renting rooms to sharing gadgets and swapping clothes [8].

According to our analysis, ING International Survey [9], Eurostat [5] and European Commission [4] data conducted in $2017,9 \%$ of US respondents have participated in the sharing economy, using technology to connect with peers to transact goods and services. In European Union $5 \%$ of respondents have participated in the sharing economy. But we see the increase in regions (according the answers of the respondents). About a third of people in Europe think that their participation in the sharing economy will increase in the next 12 months (Fig. 1).

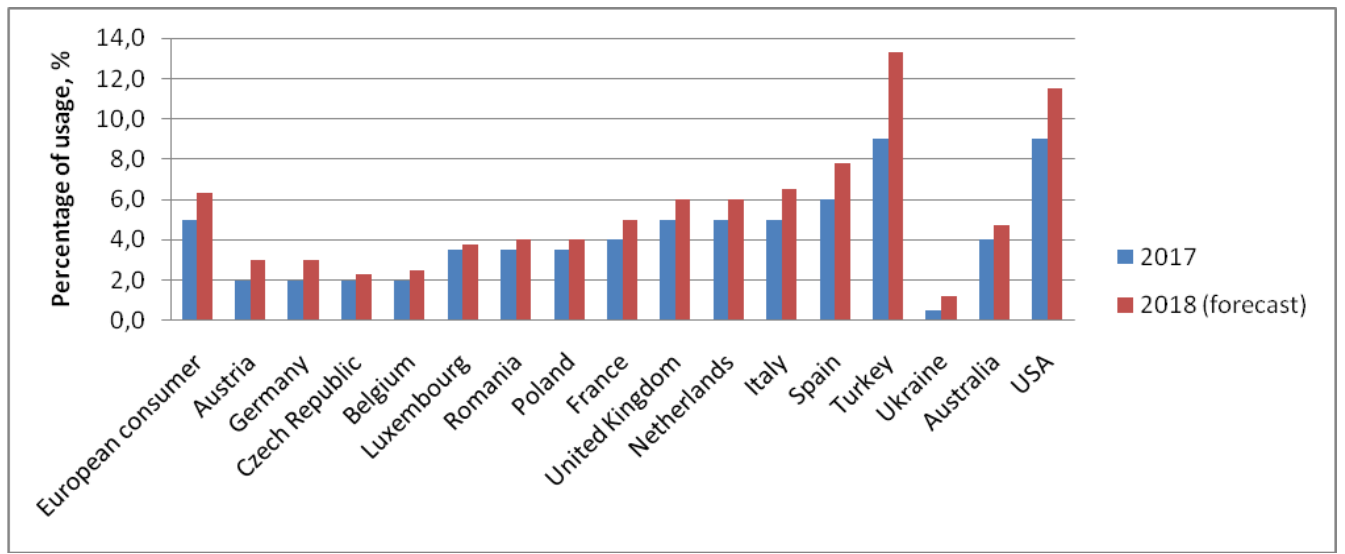

Source: own processing, data extracted $[4,5,9]$. Note: sample size: 14,829

Figure1. Usage the sharing economy within countries in 2017 (forecast to 2018)

The collaborative economy describes a set of technologies and market forces that encompass very different kinds of behaviours and transactions. We can see in the picture 2 the 
most of popular sharing economy services in different country according the research of ING [9] and European Commission [4].

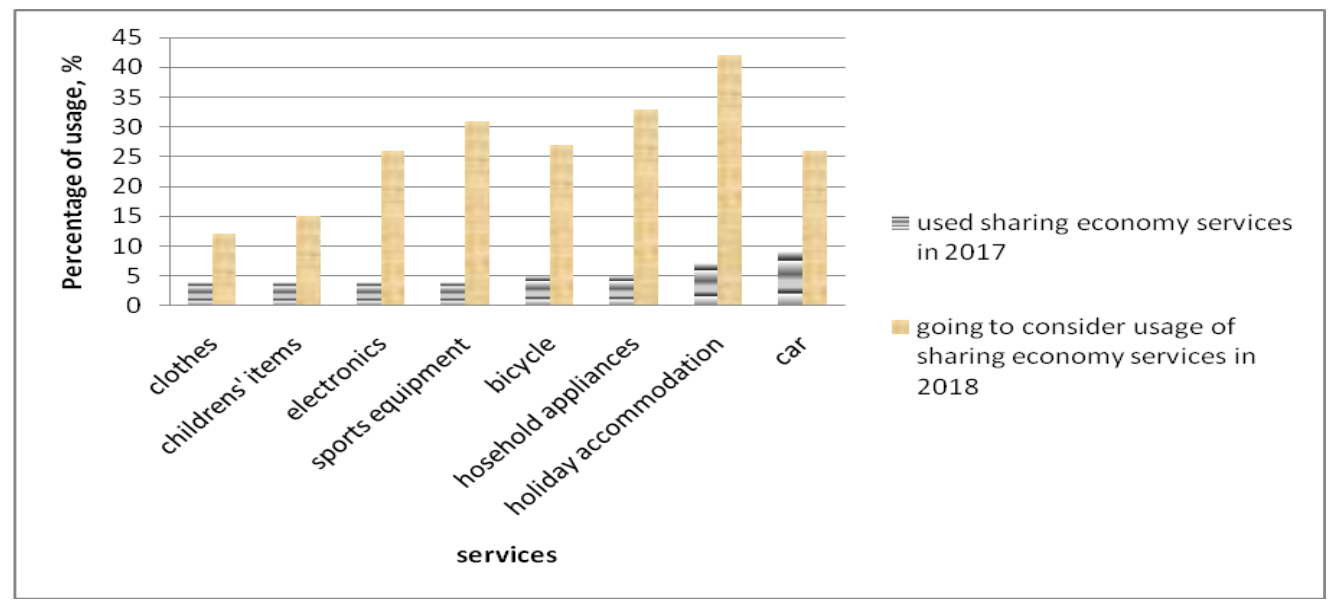

Note: sample size: 12,77

Figure 2. Most popular services of the sharing economy [4, 9]

As we can see, most respondents in different country borrowed a car over the last 12 months - but housing rent could become more popular in the near future. There is less acceptance of paying for borrowed clothes and electronics. The proportion for children's items (such as toys) is likely to be larger among parents.

So, collaborative consumption is a socio-economic model in which people are able to use the goods and services collectively. Exchange, lease and donation forms the basis of it [4]. Collaborative consumption is a relatively new phenomenon. Schering economy was originated in the 2000s in the field of IT. Initially the idea was to share the computer resources. Then automobiles, bicycles, clothing, apartments, etc. came to the fore. Young people are main consumers of cheap sharing services over the Internet. Using platform like "Kleiderkreisel" they exchange clothing, engage in "couchsurfing" or could just rent a drilling machine of their neighbours for a few hours. Many people justify it by the need to save limited resources and act ecologically. Entrepreneurs also discovered a new trend. For example, "carsharing" became extremely lucrative business model of automobile firms. Federal Union of CarSharing even considers that it is possible to speak about a new "culture of mobility" and the growing interest for motorists in Germany. By the beginning of 2015, In 150 German centers of "carsharing" (short-term rental) is already to about 1 million participants of this program. "Carsharing" services available in 490 cities and municipalities in Germany, which is 110 more than in 2014 year.

The rate of development of sharing economy in America and Europe are very high [3]. In 2011 the magazine "Time" included the phenomenon of sharing economy into the top ten ideas that would change the world [12]. In Ukraine, The sharing economy grows more slowly, and there are a few studies of new forms of consumption.

Thus, the main objective of this research is to describe a context of appearance and existence of forms of collaborative consumption in the world and in Ukraine. 
It is worth mentioning that, sharing economy arose long time ago. Sharing things and services "an acquaintance" we have always existed. Today, due to the fact that the Internet and social networks provide communication between the most distant regions of the world, sharing economy includes both sales and exchange of basic household goods and services of shortterm apartments rental and search for travel companions for trip around the city or long distances. In other words, for example, if you have clothes or things that you, for whatever reasons, do not use, you can exchange or sell it to another person for a modest fee. This is the simplest situation, which shows the usefulness of sharing economy to society. If we evaluate the real trend of sharing economy today it is gone far enough beyond the simple exchange of things. This model opens up the possibility of consumption in which the money is either not used or have secondary importance, and the reputation of participants comes to the fore in these operations [1]. Collaborative consumption is a key element of the economy of exchange.

The key publication so far on the sharing economy is the book "What's mine is yours" by Rachel Botsman and Roo Rogers [2]. Their overarching conceptual framework differentiates between three features of the sharing economy: 1) product services systems (PSS); 2) redistribution markets; 3) collaborative lifestyle. Alongside product service systems, such as "carsharing" or leasing machinery tools and redistribution markets - from second-hand shops to Ebay, they elaborate the idea of collaborative consumption as a new form of peer-topeer sharing. The concept involves individuals exchanging, redistributing, renting, sharing, and donating information, goods, and talent, either organizing themselves or via commercial organization by social media platforms. According to the authors, this collaborative lifestyle will disrupt mainstream economies and consumerism, improve social cohesion, and contribute to the minimization of resource use. Despite the euphoric tone with which these processes are described, and the focus on collaborative peer-to-peer consumption, the book is helpful in suggesting what potential form a sharing economy might take [2].

Thus, the author believes that technology can create a trust between people (initially relationships are built with help of interpersonal interaction but not transaction). Trust is built on reputation, that is the measurement of how much the community trust you: we leave traces on the reputation or social capital of individuals by revocations, likes, comments.

The Pricewaterhouse Coopers [10] has formulated the concept of "sharing economy" as "an emerging ecosystem that monetize underused assets or allows to refrain from buying these assets in favour of loans, leases or service in exchange for access to the assets or money".

Airbnb (housing rental around the world), Uber (taxi drivers search service), SnapGoods (items and technology rental service) and Spotify (music sharing) works on these principles. Many consumers, especially young people, consider the right of ownership as a quite expensive burden.

New business models provide consumers with cost-effective, convenient options that inspire confidence and generate a sense of community.

History of American startup Airbnb that turned over a world tourism industry began in 2007 when its founders decided to try rent out a room for visitors of design industry conference for in Los Angeles. All hotels were filled that is why the room in where three companions placed inflatable mattress had great success.

The first transaction inspired young people to create a website where everybody could rent out their apartment or house. Subsequently, this startup has become one of the best "graduates" of famous business incubator Y Combinator. A number of venture funds including Sequoia Capital invested in it. In 2015, More than 16 million travellers used Airbnb service. Airbnb Commission is $3 \%$ of the lessor and 6-12\% of the lessee (depending on the 
duration and cost of the lease). Thus Airbnb has become a real catalyst of sharing economy and gave a start to the huge numbers of startups of joint consumption worldwide.

About a hundred of companies offering a small charge to those who are willing to share their things with others, appeared in the United States over past four years. "Sharing economy - is not just a couple of notable cases. I think that this is a serious trend, - Joe Kraus admitted, general partner of the investment fund Google Ventures that maintain the site of private cars rental and RelayRides SideCar. Company intermediaries grow because they help you to find the right thing as quickly as if it belonged to you" [8].

Now everyone can both consume and earn as a supplier. Venture capitalist Sherwin Pishavar from company Menlo Ventures, who invested in Getaround, TaskRabbit, Uber and other similar startups, said, "I'm sure that these services dramatically change the economy of city. It's much more than just a kind of model of usage, - he explained. - Sharing Movement is also as important event as the appearance of the browser" [8].

Now we consider the world's most popular sites, working in the field of sharing economy (Table 1).

Table 1

Top popular services of sharing economy in the world

\begin{tabular}{|c|c|}
\hline $\begin{array}{l}\text { The name of the } \\
\text { project }\end{array}$ & Area of business and history of success \\
\hline 1 & 2 \\
\hline Airbnb & $\begin{array}{l}\text { Service of short-term housing rental } \\
\text { This startup received the first serious investments (112 millions dollars } \\
\text { from Andreessen Horowitz, DST Global и General Catalyst) and international } \\
\text { recognition (in } 2012 \text { it was booked through the site about } 12-15 \text { million nights in } \\
\text { more than } 33,000 \text { cities in } 192 \text { countries). } \\
\text { Now Airbnb is fighting for the legalization of their activities in New York, San } \\
\text { Francisco. }\end{array}$ \\
\hline $\begin{array}{l}\text { Rover.com, } \\
\text { DogVacay }\end{array}$ & $\begin{array}{l}\text { The alternative to hotels for dogs. (Airbnb for pets) } \\
\text { The service Rover.com recently raised } 7 \text { million dollars investments. }\end{array}$ \\
\hline Lyft & $\begin{array}{l}\text { This is a privately held American transportation network company (TNC) based } \\
\text { in San Francisco. The company's mobile-phone application facilitates peer-to-peer } \\
\text { ridesharing by connecting passengers who need a ride with drivers who have a } \\
\text { car. As a bonus - insurance coverage of } 1 \text { million dollars to any incident when a } \\
\text { passenger is in the car. } \\
\text { Lyft operates in about } 65 \text { US cities, including San Francisco, Los Angeles, and } \\
\text { New York City, with plans to expand domestically and internationally. This } \\
\text { startup received } 333 \text { mln. Dollars investments for two years (2013-2014). }\end{array}$ \\
\hline BlaBlaCar & $\begin{array}{l}\text { BlaBlaCar connects drivers and passengers willing to travel together between } \\
\text { cities and share the cost of the journey. BlaBlaCar has more than } 20 \text { million } \\
\text { members across } 20 \text { countries. As of April 2015, the company had raised } \\
\text { USD } \$ 100 \text { million from blue-chip venture-capital firms including ISAI, Index and } \\
\text { Accel, plus earlier rounds of } € 1.2 \text { million from ISAI and } € 600,000 \text { from founders, } \\
\text { friends, and family. }\end{array}$ \\
\hline $\begin{array}{l}\text { RelayRides and } \\
\text { Getaround. } \\
\text { A similar option } \\
\text { for cyclists is } \\
\text { Liquid }\end{array}$ & $\begin{array}{l}\text { These are online car sharing or peer-to-peer carsharing services that allows drivers } \\
\text { to rent cars from private car owners, and owners to rent out their cars for payment } \\
\text { (unlike Zipcar). Owners set their rental prices and earn a } 60 \% \text { commission from } \\
\text { their rental revenue. } \\
\text { For instance, Getaround has received } \$ 19 \text { million USD in seed funding from } 2011 \\
\text { till 2015. The companies currently operate rentals in the San Francisco Bay Area, } \\
\text { San Diego, Austin, Portland, Chicago, Washington and so on. }\end{array}$ \\
\hline
\end{tabular}




\begin{tabular}{|l|l|}
\hline \multicolumn{1}{|c|}{1} & \multicolumn{1}{|c|}{2} \\
\hline $\begin{array}{l}\text { ParkatmyHouse } \\
\text { and Parking } \\
\text { Panda }\end{array}$ & $\begin{array}{l}\text { The online parking services that allow drivers to find and reserve parking in } \\
\text { advance. In addition to providing drivers with mobile and web applications to find } \\
\text { parking, they also help parking garage owners manage their inventory. According } \\
\text { to the creators ParkatmyHouse, active users earn more than a thousand dollars a } \\
\text { year. } \\
\text { Car owners can save on the cost of the good parking - according Parking Panda, } \\
\text { up to 70\%. }\end{array}$ \\
\hline Postmates & $\begin{array}{l}\text { This is a logistics company, which allows you to transfer in the city parcels } \\
\text { quickly without resorting to the services of courier services. Users of the service, } \\
\text { who has free time, can transfer your parcels for a small fee. }\end{array}$ \\
\hline $\begin{array}{l}\text { Zilok, Rentoid, } \\
\text { SnapGoods }\end{array}$ & $\begin{array}{l}\text { Web services allow every user to rent the necessary thing to him. Customers can } \\
\text { evaluate the product before purchasing, taking it rented for a few days. They also } \\
\text { have the ability to use the product, which is necessary for them for one day. In } \\
\text { addition, owners of different things (necessary and unnecessary) can earn money } \\
\text { by renting out their things. }\end{array}$ \\
\hline $\begin{array}{l}\text { TaskRabbit, } \\
\text { YouDo, GF }\end{array}$ & $\begin{array}{l}\text { The online and mobile marketplaces that allow users to outsource small jobs and } \\
\text { tasks to others in their neighborhood. Users name the task they need done and the } \\
\text { price they are willing to pay, and a network of pre-approved contractors bid to } \\
\text { complete the job. }\end{array}$ \\
\hline
\end{tabular}

Source: own processing data extracted from $[7,9,10,12,13]$

According to research by Kelvin Claveria [13] survey, it is considered that by 2017, eight of ten Americans will be involved in co-consumption economy. Six of ten people will use these services next year. If crowds of users already use these services, how will ordinary companies be able to accept them? Will they follow the example of the supermarket Whole Food Market (everyone can order some goods through the mobile app and pick them up at any store or get home delivery); whether they will cooperate as McDonald's, Starbucks and Walgreens, with service delivery Postmates; whether they will join the new economy, as Mitchells, Hallmark and Hershey's did, taking part in exhibitions of designers and makers Brit + Co. It's show time. However, the traditional economy companies need to understand that $82 \%$ of sharing transactions motivated by the low price. Brands can take advantage of this opportunity to keep or to entice customers of such services.

According to research by Davis Yellen [7] estimates, the turnover of sharing economy in 2015 year exceeded 3.5 billion dollars. That is $25 \%$ more than the year before. Such increase does not allow to say that is just a side perk but the economic trend especially when there is a market stagnation of wages in the United States. Development of technologies speed up movement in this direction. Electronic auction Ebay introduced a rating system that helps to assess the reliability of the counterparty. From your Facebook profile, you can watch it. Applications for smartphones are helping to make a transaction, look for the best deals around and pay.

The concept of sharing helped to create a new market of resources, which have never been presented as a current economic asset

In Ukraine, the sharing economy came partly due to the economic crisis. According to the press service of the OLX company, since November 2014 to April 2015, the number of searches for the keyword "rent" has increased by $60 \%$ on average. What are the Ukrainian projects that comply with the concept of sharing economy? 
1. Co-working space (shared use of office). Creative space "Chasopis" appeared one of the first in 2013 in Kiev. The most active visitors are businessmen, people 25-35 years old, people who make their projects or wish to become entrepreneurs. Workspace can be rent for an hour, but can be booked for a month. In addition to the workstation with internet access, guests can use the meeting room, to hold Skype conference, to print the document and have a coffee. Besides the the "Chasopis" there is a dozen of similar projects in Kiev, for instance, anticafe "Time wagon", "Dial Color" coworking center "Holosiivskyi", Startup Ukraine, Freud House, coworking in Taras Shevchenko National University of Kyiv and National Technical University of Ukraine "Kyiv Polytechnic Institute".

2. Rent a Brand, OhMylook - exchange services and rental of branded dresses. The need for these services is to solve the typical problems of girls: nothing to wear to the event and there is nowhere to store. Clients of the services are girls between 23 and 40 years who are working to provide themselves and realize that they could hardly put on festive clothes many times. During the first year of existence, the service increased by 3 times and continues to grow. For instance, division of company OhMylook is located in Kiev and Odessa, the owner talks to sell the franchise to other countries.

3. Baby Service - rental service for baby goods. Children grow up very quickly, so buying of all the tools that may be needed, and may not be used for development of the child is impossible. That is why children's clothes rental service has become popular quickly enough by itself. Today Baby Service is represented in 22 cities of Ukraine.

4. Bag2Rent - service lease bags and suitcases. This business idea is to give to the rental suitcases for a fee.

5. GiveMeALift is a geolocation service for those who want to get somewhere, and those who want to lift someone. Using it, passengers will be able to find a car quickly that will drive up to the destination, appropriate passenger for drivers. GiveMeALift application will compare all passengers and drivers, and notify both about suitable routes. The driver has to confirm intentions to pick a passenger and ride to a destination. To use the service, each user logs into it with the help of Facebook or Google+ accounts. So you always know, who is your driver or fellow traveler. Service is under construction, but trial version acts in Kiev.

6. Veliki.ua - service of bicycle rental. The motives of creation were the dissatisfaction with the high cost of service and rental bicycles. This service was created in 2009. In May 2011, a bicycle rental totaled three points in Kiev, now it works in ten cities of Ukraine. It noted strong growth of demand for the service over the past three years. If we compare 2014 to 2013 , demand for services increased by $35 \%$.

It also becomes known that Uber is going to enter Ukrainian market. (mobile application used for search and calling a taxi or the payment to private drivers). But it is still under development in Ukraine.

New players that appear in different segments of the market, of course, make nervous representatives of the traditional business. Today, freelancers compete successfully with design studios, legal bureau, software companies, and at the same time invade the zone, which traditionally belonged to recruitment agencies. Specialized companies, that have been monopolies in their segments, suddenly face the emergence of new aggressive players whose total turnover in the market every year adds from 100 to $500 \%$. At the same time representatives of the new economy are not forced to remain within sharing: it all depends on the situation. As well as P2P-sites may strive to get a banking license and become a bank, traditional banks may use sharing technology agreement in search of new profits. Anyway, Sharing companies have a great advantage in comparison with traditional, because they can 
quickly overtake competitors. The essence of one of the main concepts of the Japanese School of Economics is to defeat the enemy where there is no him. Sharing economy is of course connected with a number of risks, because one of the main factors of it is human.

The prospect of sharing economy is not in doubt. That is why today, a sufficient number of companies seeking to develop in this direction. According to research by ING [9] conducted among 30,000 Internet users in 60 countries, showed that about $68 \%$ of the respondents are willing to share their personal assets to others for financial gain. Trend "share economy" is reflected in the world of corporate business of large companies. For example, in May 2015 year, Google said it has spent the last 12 months of about 2 million dollars on service Airbnb.

The idea of "sharing agreement" forces us to reassess values of the "consumer society" Rational usage of things, instead of mindless ownership is particularly relevant in the context of caring of the environment and the need for careful treatment to limited resources.

Thus, after analysis, we can identify the main drivers of growth of the sharing economy:

1. The growing influence of information technology on communication of individuals, organizations and as a whole. Personal data of most of users is opened, and mobile technologies become more accessible than before.

2. Population growth, the increase of urban population density leads to the need of sharing resources and services.

3. The increase in income inequality (the gap between incomes of rich and the poor)

4. Global financial, environmental and social crisis (falling incomes, unemployment and insecurity) leads to more definitively control cost.

5. Natural disasters (the earthquake in Japan, the tsunami, the Chilean earthquake, hurricanes, droughts, etc.).

6. Social disturbance in the world, which affects changes in the economic and social environment.

7. The rapid increase in volatility of the value of natural resources. Humanity is increasingly starts turning to alternative energy sources.

8. Stable growth of sharing economy over the past few years. The Economist [11] estimates the global market of sharing economy on the Internet at 26 billion dollars. The sharing economy is increasingly influences a number of "traditional" sectors. Also "classical" companies have a great interest for sharing economy models and implement its elements in their own business model.

Economists have not yet decided how to evaluate the sharing economy. They are faced the question: Is the result of sharing economy new value or a simple replacement existing business. A short-term negative effect on the economy as a result of a person's rejection to buy a new thing is always possible. Nevertheless, in the long term, the economy wins. In 2012, Airbnb commissioned a study of the impact of their business in San Francisco and discovered a "stunning effect". As Airbnb proposals are cheaper than hotels, visitors lived in rented accommodation longer and, therefore, left on average, 1,100 dollars more money in the city, while the tourists staying at the hotel spend 840 dollars. And $14 \%$ of respondents said they would not come to San Francisco, if not Airbnb $[4,10]$.

Some critics do not consider these services seriously, regarding their business casual trend that emerged in difficult economic times. Also security, discrimination, customer service and quality goods are disadvantages of sharing economy. Problems in taxation and interaction with the authorities remain unsolved.

Sharing economy companies are also interested in their reputation and trying to solve all these problems introducing compulsory insurance for drivers and collecting hotel taxes. Thus, 
it is not necessary to bun sharing economy business but to create clear rules of the new popular business.

Conclusions and prospects of further research. It should be noted in the age of sharing, companies need to better anticipate and resolve customer issues, boost their brand affinity and drive customer loyalty. Achieving all of these requires customer intelligence that's rooted in ongoing engagement with the increasingly empowered customer. When customers are in charge and can easily avoid traditional methods of buying, you need to be in tune with the why of their behaviours and be nimble enough to make the necessary changes to your business.

Companies working in sharing economy will be developing for some time. For the market of post-Soviet countries (including Ukraine) this area is still new. To overcome certain "barrier" of perception of customers the potential audience should be prepared to a new service through the active promotion. This policy should include economic incentives to stimulate sharing economy start-ups, planning approaches with regard to shared (public) spaces or coordination and information measures to stimulate innovation and adoption of sharing models between different societal groups from business, through entrepreneurship to administrative bodies.

\section{References}

1. Botsman, R. (2012). The currency of the new economy is trust. Retrieved from http://www.ted.com/talks/rachel_botsman_the_currency_of_the_new_economy_is_trust?language=e g.

2. Botsman, R., Rogers, R. (2010). What's Mine is Yours: The Rise of Collaborative Consumption. N.Y.: HarperColllins Publishers.

3. Vitaud, L. (2015). The Gig Economy in Spain: From the Shadow to the Light. Retrieved from https://medium.com/switch-collective/the-gig-economy-in-spain-from-the-shadow-to-the-light829e9d9a48cd.

4. European Commission. (2017). Collaborative economy. Retrieved from http://ec.europa.eu/growth/single-market/services/collaborative-economy_en.

5. Eurostat. (2017). Online peer-to-peer accommodation services used by 1 in 6 EU citizens. Retrieved from http://ec.europa.eu/eurostat/web/products-press-releases/-/9-20122017-AP.

6. Fellander, A., Ingram, C., Teigland, R. (2015). The Sharing Economy Embracing Change With Caution. Stockholm: Entreprenörskapsforum.

7. Yellen, D. (2015). Airbnb, Snapgoods and 12 More Pioneers Of The 'Share Economy'. Retrieved from http://www.forbes.com/pictures/fljh45flh/airbnb-snapgoods-and-12-more-pioneers-of-theshare-economy.

8. Heinrichs, H. (2013). Sharing economy: A potential new pathway to sustainability. GAIA Ecological Perspectives for Science and Society, 4(22), 228-231.

9. ING. (2017). Mobile Banking 2017 - Newer Technologies. Retrieved from https://www.ezonomics.com/ing_international_surveys/mobile-banking-2017-newer-technologies/.

10. Pricewaterhouse Coopers (PWS). (2017). PwC's Global Annual Review 2017. Retrieved from https://www.pwc.com/gx/en/about/global-annual-review-2017.html.

11. The Economist. (2013). The rise of the sharing economy. Retrieved from http://www.economist.com/news/leaders/21573104-internet-everything-hire-rise-sharing-economy.

12. Time Magazine. (2011). 10 Ideas that Will Change the World. Retrieved from http://content.time.com/time/specials/packages/0,28757,2059521,00.html.

13. Claveria, K. (2015). How to compete with the next Uber: New rules for the collaborative, ondemand, sharing economy. Retrieved from https://www.visioncritical.com/new-rules-in-sharingeconomy.

Manuscript received 12 April 2018 
В. В. Гончар, Т. В. Горохова, О. В. Калінін. Ефект

конкурентоспроможності шерингової економіки. Світові і українські реалії

Эффект конкурентоспособности шеринговой экономики. Мировые и украинские реалии

\section{ВИКТОРИЯ ВАСИЛЬЕВНА ГОНЧАР*, ТАТЬЯНА ВАДИМОВНА ГОРОХОВА**, АЛЕКСАНДР ВЛАДИМИРОВИч КАЛИНИн ${ }^{* * *}$ \\ * доктор экономических наук, дочент,} заведующая кафедрой маркетинга и бизнес-администрирования ГВУЗ Приазовского государственного технического университета, ул. Университетская, 7, г. Мариуполь, 87500, Украина, тел.: 00-380-667256245, e-mail: gonchar.mariupol@gmail.com

** кандидат экономических наук, доиент кафедры маркетинга и бизнес-администрирования ГВУЗ Приазовского государственного технического университета, ул. Университетская, 7, г. Мариуполь, 87500, Украина тел.: 00-380-662238656, e-mail:tanyagorokhova88@gmail.com

**** кандидат экономических наук, дочент кафедры маркетинга и бизнес-администрирования ГВУЗ Приазовского государственного технического университета, ул. Университетская, 7, г. Мариуполь, 87500, Украина, тел.: 00-380-966387474, e-mail: kalininandkalinin@gmail.com

В современной жизни потребление является неотъемлемой частью жизни. Однако в последние годы много дискуссий о негативных последствиях роста потребления из-за ограниченных ресурсов, перенаселенности Земли, неравномерного распределения природных богатств и изменения климата. Осведомленность по этим вопросам получила ответ в ряде развитых стран в виде возникновения альтернативной экономики. Принципы экономики основаны на отрицании ценностей потребления и непостоянного движения для товаров. Этот тип экономики, называемый шеринговой экономикой, является социально-экономической моделью, где люди имеют доступ к коллективному потреблению. Стоит упомянуть, что научных работ, посвященных этому вопросу, недостаточно, и он до сих пор не исследован. Это объясняет актуальность выбранной темы. В статье были проанализированы основные аспекты рождения экономики совместного использования, преимущества основных рисков, связанных с развитием экономики совместного использования. Мы рассмотрели и проанализировали основные международные обмены международной практикой и обобщенный опыт Украины в реализации проектов совместного использования экономики. Постоянно растет число компаний из сфер шеринговой экономики. Также быстрыми темпами растет капитализация этих компаний (как частных, так и публичных). Эти компании также попадают в списки наиболее перспективных стартапов и внедряют инновации в свой бизнес-процесс. Компании данной сферы все активнее составляют конкуренцию лидерам рынков, на которых они представлены. Можно также сказать, что данные предприятия заново формируют рынки и отношения на них. Исходя из данных фактов можно сказать, что интерес науки к данной теме является актуальным. В статье были исследованы главные сферы шеринговой экономики на сегодня и наиболее крупные компании из этих сегментов. Также было проведено исследование стран, в которых наиболее активно развиваются данные компании с прогнозированием роста, также сделаны выводы относительно развития данных сегментов, особенно на развивающихся рынках.

Ключевые слова: шеринговая экономика, совместное потребление, стартап. 
Victoriya V. Gonchar, Tetiana V. Gorokhova, Oleksandr V. Kalinin. Competitiveness Effect of Sharing Economy. World and Ukrainian Realities

Mechanism of Economic Regulation, 2018, No 2, 59-69

ISSN 1726-8699 (print)

Ефект конкурентоспроможності шерингової економіки.

Світові і українські реалії

\section{ВІКТоРІя ВАСИЛІВНА ГОНЧАР*, ТЕТЯНА ВАДИМІВНА ГОРОХОВА ${ }^{* *}$, ОЛЕКСАНДР ВОЛОДИМИРОВИч КАЛІНІн ${ }^{* * *}$}

* доктор економічних наук, дочент, завідувач кафедри маркетингу

та бізнес-адміністрування ДВНЗ Приазовського державного технічного університету, вул. Університетська, 7, м. Маріуполь, 87500, Украӥна, тел.:00-380-667256245, e-mail: gonchar.mariupol@gmail.com

*** кандидат економічних наук, дочент кафедри маркетингу та бізнес-адміністрування ДВНЗ Приазовського державного технічного університету, вул. Університетська, 7, м. Маріуполь, 87500, Украӥна, тел.:00-380-662238656, e-mail: tanyagorokhova88@gmail.com

**** кандидат економічних наук, дочент кафедри маркетингу та бізнес-адміністрування ДВНЗ Приазовського державного технічного університету, вул. Університетська, 7, м. Маріуполь, 87500, Украӥна, тел.:00-380-966387474, e-mail: kalininandkalinin@gmail.com

У сучасному житті споживання є невід'ємною частиною життя. Однак в останні роки багато дискусій про негативні наслідки зростання споживання через обмежених ресурсів, перенаселення Землі, нерівномірного розподілу природних багатств і зміни клімату. Поінформованість $з$ цих питань отримала відповідь в ряді розвинених країн у вигляді виникнення альтернативної економіки. Принципи економіки засновані на запереченні цінностей споживання і непостійного руху для товарів. Цей тип економіки, званий шеринговою економікою, є соціально-економічною моделлю, де люди мають доступ до колективного споживання. Варто згадати, що наукових робіт, присвячених цьому питанню, недостатньо, і він до цих пір не досліджений. Це пояснює актуальність обраної теми. У статті були проаналізовані основні аспекти народження економіки спільного використання, переваги основних ризиків, пов'язаних з розвитком економіки спільного використання. Ми розглянули і проаналізували основні міжнародні обміни міжнародною практикою і узагальнений досвід України в реалізації проектів спільного використання економіки. Постійно зростає чисельність компаній зі сфери шерингової економіки. Також швидкими темпами зростає капіталізація цих компаній (як приватних так і публічних). Ці компанії також потрапляють до списків найбільш перспективних стартапів і впроваджують інновації у свій бізнес-процес. Компанії цієї сфери все активніше складають конкуренцію лідерам ринків, на яких вони представлені. Можна також сказати, що ці підприємства наново формують ринки і стосунки на них. Виходячи 3 цих фактів можна сказати що інтерес науки до цієї теми $\epsilon$ актуальним. У статті були досліджені головні сфери шерингової економіки на сьогодні і найбільш великі компанії з цих сегментів. Також було проведено дослідження країн, в яких найактивніше розвиваються ці компанії з прогнозуванням росту, також зроблені висновки відносно розвитку цих сегментів, особливо на розвиваючих ринках.

Ключові слова: шерингова економіка, спільне споживання, стартап.

JEL Codes: M13, M31, F23.

Table: 1; Figures: 2; References: 13

Language of the article: English 